\title{
REJTETT GALÉRIÁK: AZ ÜLDÖZÖTT VALLÁSOSSÁG KÉPEI A TITKOSSZOLGÁLATI LEVÉLTÁRAKBAN
}

\author{
POVEDÁK KINGA
}

A valláskutatás hosszú ideje létező problémája, hogy a diktatórikus rendszerek vallási kultúrájáról csak korlátozott ismeretanyaggal rendelkezünk. Kutatható és kutatják is a hivatalos valláspolitika szintjét, az egyház-állam kapcsolatokat, a vallási üldöztetést, ám objektív okok folytán a hétköznapi vallási kultúra folyamatairól, arról, ami a mindennapok részét képezte, alig rendelkezünk ismeretekkel. Diktatórikus rendszerek - pláne, ha olyan szinten vallásellenesek, mint a kommunizmus - sosem preferálták a saját jelenkoruk kutatását, hiszen abból olyan folyamatok, helyzetek kerülhettek volna fényre, amit az adott rendszer igyekezett elkendőzni. Ennek következtében tisztában vagyunk például azzal, hogy a totalitárius kommunista rezsimek hogyan és mikor számolták fel a civil szférát, szüntették be a vallási egyesületeket, zárták be a szerzetesrendeket, egyházi iskolákat, vagy törték meg koncepciós kirakatperekben az egyházakat, ám arról, hogy milyen módon éltek tovább korábbi korok vallási gyakorlatai a privát szférába számüzött vallási kultúrában, milyen megújulási mozgalmak és újabb vallási mozgalmak jelentek meg; vagy arról, hogy a hatóságok szeme elől elrejtőzni kénytelen házi gyülekezetek, csoportok, rítusok milyen módon, milyen mintára épültek fel, az ilyen közösségek milyen struktúrába rendeződtek, ha rendeződtek, honnan szerezték be „tudásuk”, már nem rendelkezünk ismeretekkel. Ebből a szempontból számít izgalmas és rengeteg új eredményt ígérö kezdeményezésnek az Európai Kutatási Tanács (ERC) által támogatott Creative Agency and Religious Minorities: 'Hidden Galleries' in the Secret Police Archives in Central and Eastern Europe kutatási projekt, melynek házigazdája a University College Cork (Írország) Vallástudományi Tanszéke. A kutatócsoport vezetője, James Kapaló irányítása alatt közép- és kelet-európai kutatókból álló team jött létre (Iuliana Cindrea, Anca Sincan, Gabriela Nicolescu, Dumitru Lisnic és Tatiana Vagramenko), melyben Magyarországról Hesz Ágnes, a PTE Néprajzi és Kulturális Antropológiai tanszékének munkatársa és Povedák Kinga, az MTA-SZTE 'Convivence’ Vallási Pluralizmus Kutatócsoport munkatársa vesz részt.

A Hidden Galleries projekt kutatói négy ország - Magyarország, Románia, Ukrajna és a Moldovai Köztársaság - titkosrendőrségi levéltárainak anyagai alap- 
ján a totalitárius uralom alatt létező vallási csoportok kreatív túlélési gyakorlatait vizsgálják. A kutatás újszerü megközelítésének alapja, hogy olyan fényképek és szövegek gazdag gyüjteményét is felhasználják az elemzések során, melyeket épp a titkosrendörség ügynökei koboztak el azért, hogy a vallási csoportok tagjait gyanúba keverhessék. Emellett természetesen elemzik a titkosrendőrségek dokumentációját is, a beépített ügynökök jelentéseit, a megfigyelési akciók közben készített fotókat, amiket az adott közösségek megfigyelésére, ellenőrzésére vagy akár likvidálására használtak fel.

A projekt azonban nem horgonyoz le a történelmi olvasatoknál, hanem fontos célkitüzése, hogy a kutatott vallási csoportokat felkeresse, és a forrásokban szereplő túlélő személyekkel, illetve hozzátartozóikkal interjúkat készítsenek, hogy teret adjanak az egykor üldözött vallási közösségek hangjának. A kutatási folyamat során hangsúlyos szereppel bír a titkosrendőségi anyagok megismertetése az adatközlőkkel, hogy a levéltári forrásokból kirajzolódó eseményeket egy személyesebb olvasattal egészítsék ki. Illetve azért is, hogy a múlt lenyomatait, saját vallási kultúrájuk általuk nem ismert - ám paradox módon épp a titkosrendőrség által megőrzött - örökségét, emlékeit eljuttassák hozzájuk.

Az ilyen jellegü, korábban alig vagy más szemszögből vizsgált források és etnografikus módszerek segítségével az eddigi elképzeléseknél árnyaltabb és gazdagabb kép nyerhető a diktatúra alatti megélt vallásosságról. A projekt külön érdekessége, hogy mindezek mellett elsősorban a vallási kisebbségekre és a kevésbé kutatott lokális szintű karizmatikus vallási szervező egyénekre és vallási közösségekre koncentrál, felszínre hozva olyan vallási folyamatokat, mentalitásokat, jellegzetességeket, melyekről eddig a vallástudományi kutatás nem vagy alig rendelkezett információkkal.

A Hidden Galleries projekt működésének négy éve alatt az általuk megszerzett tudást több formában juttatja vissza a társadalom felé. A szaktudományos publikációk, tanulmánykötetek, ${ }^{1}$ konferenciák mellett kiemelkedő jelentőségü a kutatócsoport digitális adatbázisa (http://hiddengalleries.eu/digital-database/), melyen keresztül mindenki számára elérhetővé válnak és megismerhetők a már feldolgozott anyagok. Mindezek mellett a projekt jelentős eredménye egy négyrészes kiállítássorozat, ami a projekt munkálatai során kutatott országok mindegyikében, az adott titkosszolgálati forrásokkal aktualizáltan kerül kialakításra. Magyarországon a Hit - Bizalom - Titok címü kiállítás 2020. február 28-án nyílt meg az OSA Blinken Archívum Centrális Galériájában, majd a pandémia következtében az online

\footnotetext{
${ }^{1}$ Már megjelent James Kapaló and Tatiana Vagramenko (eds.): Hidden Galleries. Material Religion in the Secret Police Archives in Central and Eastern Europe, LIT Verlag, Zürich, 2020. Jelenleg szerkesztés alatt áll James Kapaló, Kinga Povedák (eds.): The Secret Police and the Religious Underground in Communist and Post-Communist Eastern Europe, Routledge, 2021.
} 
térbe költözött, és a mai napig is elérhető az alábbi felületen: https://www.osaarchivum.org/node/1473.

A kiállítás nem véletlenül viseli ezt a nevet. A hit és a bizalom fontos alapkövei a vallási közösségeknek, de - mint jól tudjuk - a vallások és a vallási csoportok közös jellemzője a titokzatosság is. Mindezek mellett a titkosrendőrség működése során is fontos szereppel bírt a hit (akár a hívek esetében, akár az ügynökök „politikai vallásánál"); a titok és a titoktartás különböző - valódi vagy megjátszott - gyakorlatai; valamint a bizalom, hiszen leplezett tevékenységének elemi része volt, hogy a megfigyelni és behálózni kívánt közösségek bizalmát elnyerje. A valláskutatóknak pedig - ma és a kommunizmus ideje alatt egyaránt - szintén bizalmi kapcsolatot kell kiépíteniük az általuk vizsgált közösségekkel. De ha jobban belegondolunk, érzékeny esetekben, etikai okokból a kutatók is különböző titkosítási technikákat alkalmaznak adatközlőik személyazonosságának védelmében.

A kiállítás ezt, a titkosrendőrség, a vallási csoportok és az őket tanulmányozni kívánó kutatók közötti összetett viszonyrendszert jeleníti meg. A bemutatott képeken, történetekben és vallomásokban a hit, a bizalom (akár adott, akár elveszett) és a titok egymásba fonódnak.

A projekt sok erénye mellett sajnos egy negatívumról is szólnunk kell. Mivel a Hidden Galleries kutatást az ERC támogatta, ennek következtében 2020 őszén véget ért. Ezért mindenféleképpen kár, kutatni való még lenne bőven, és valószínủleg érdeklődés is. 